\title{
Identification and Characterization of Benomyl-Resistant and -Sensitive Populations of Colletotrichum gloeosporioides from Statice (Limonium spp.)
}

\author{
Marcel Maymon, Aida Zveibil, Shimon Pivonia, Dror Minz, and Stanley Freeman
}

First, second, and fifth authors: Department of Plant Pathology, and fourth author: Institute of Soil, Water, and Environmental Sciences, ARO, The Volcani Center, Bet Dagan 50250, Israel; and third author: Arava R\&D, Sapir, 868252, Israel. Accepted for publication 9 January 2006.

\begin{abstract}
Maymon, M., Zveibil, A., Pivonia, S., Minz, D., and Freeman, S. 2006. Identification and characterization of benomyl-resistant and -sensitive populations of Colletotrichum gloeosporioides from statice (Limonium spp.). Phytopathology 96:542-548.

Sixty-four isolates of Colletotrichum gloeosporioides were isolated from infected Limonium spp. cultivated in 12 different locations in Israel. All isolates were identified as belonging to the $C$. gloeosporioides complex by species-specific primers. Of these isolates, 46 were resistant to benomyl at $10 \mu \mathrm{g} / \mathrm{ml}$ and 18 were sensitive to this concentration of fungi-

distinct genotypes. Sequence analyses of the $\beta$-tubulin genes, TUB1 and $T U B 2$, of five sensitive and five resistant representative isolates of C. gloeosporioides from Limonium spp. revealed that the benomylresistant isolates had an alanine substitute instead of a glutamic acid at position 198 in TUB2. All data suggest that the resistant and sensitive genotypes are two independent and separate populations. Because all Limonium plant propagation material is imported from various geographic regions worldwide, and benomyl is not applied to this crop or for the control of Colletotrichum spp. in Israel, it is presumed that plants are bearing quiescent infections from the points of origin prior to arrival.
\end{abstract} cide. Based on arbitrarily primed polymerase chain reaction of all isolates and internal transcribed spacer-1 sequence analyses of 12 selected isolates, the benomyl-resistant and -sensitive populations belong to two
Additional keyword: anthracnose.
Many species of the herbaceous ornamental perennial genus Limonium (Plumbaginaceae Juss.) are native to the Mediterranean region. However, due to breeders' propriety rights, plants for commercial propagation and production are imported to Israel from Europe, North America, or Australasia without a documented history of cultivation treatments. During the last decade, two main hybrids have been cultivated in commercial production in the Arava and Negev desert regions: Limonium latifolium $\times$ L. caspium (cv. Beltlaard) and L. latifolium $\times$ L. bellidifolium (cvs. Supreme, Misty, and Sunglow), that are grown primarily for export to Europe as cut flowers for floral bouquets.

Colletotrichum gloeosporioides (Penz.) Penz. \& Sacc. in Penz. is one of the most destructive diseases of Limonium spp. (12,25, 44), causing typical anthracnose symptoms (leaf, stem, and flower spot) and a crown rot that may result in $100 \%$ yield loss in the field (13). Since 1995, the crop has declined in Israel due to a wilt and death caused by $C$. gloeosporioides $(4,39)$. Propagation material may be the source of the infection because the pathogen can occur in nurseries, on young seedlings in seedbeds, and in other seedling production areas (12).

In the genus Colletotrichum, it is common to find multiple hosts affected by a single species and multiple species infecting a single host (15). For example, $C$. gloeosporioides, known to be a complex species, has been reported on many hosts besides Limonium spp., such as apple, avocado, citrus, mango, passion fruit, strawberry, and others $(1,2,16,23,38)$. Likewise, it has been reported that several Colletotrichum spp. or biotypes can be associated with a single host, such as avocado, citrus, coffee,

Corresponding author: S. Freeman; E-mail address: freeman@volcani.agri.gov.il

DOI: 10.1094/PHYTO-96-0542

(c) 2006 The American Phytopathological Society cucurbits, mango, pepper, strawberry, and tomato $(1,2,5,10,14$ 16,19,21). Although $C$. gloeosporioides is known to affect species of Limonium grown in different regions worldwide (e.g., Florida $[12,44]$, Japan [25,41], and South Korea [34]), due to the heterogeneity and wide host range of this species, as mentioned above, various genotypes and even different Colletotrichum spp. may be responsible for the disease in this crop.

It usually is difficult to control anthracnose in established Limonium plantings in the field (12); however, effective control of C. gloeosporioides in Limonium spp. has been achieved with a benomyl foliar spray (44). Benomyl resistance, however, is common in fungi, especially after multiple applications $(3,9,27$, 30,47). This fungicide, currently and in the past, has not been applied in field cultivation of Limonium spp. in Israel. To evaluate the in vitro sensitivity of selected isolates from Israel against benomyl, to support a possible registration of this fungicide, a preliminary screening for benomyl sensitivity was conducted (unpublished data). Surprisingly, it was found that the majority (approximately $75 \%$ ) of isolates were resistant to benomyl. Fungal resistance to benomyl typically is associated with point mutations in a $\beta$-tubulin gene that changes the amino acid sequence at the benzimidazole binding site (27). Codon changes reported are at positions 50, as in Cladobotryum dendroides (32); 198 and 200, as in Tapesia spp. (3) (e.g., in Venturia inaequalis [27], Botrytis cinerea [28,47], and Penicillium spp. [27]); or at positions 240, as in Tapesia spp. (3). Two $\beta$-tubulin genes have been described for some Colletotrichum spp. $(6,23,37,38)$. In $C$. graminicola infecting maize and in $C$. gloeosporioides $\mathrm{f}$. sp. aeschynomene affecting Northern jointvetch (Aeschynomene virginica (L.)), the two genes, $T U B 1$ and $T U B 2$, have only 73 and $69 \%$ sequence identity, respectively $(6,37)$. A point mutation in TUB2 that results in a substitution of a glutamic acid for a lysine at amino acid 198 confers benomyl resistance in both species $(6,37)$. 
In light of our findings that the majority of C. gloeosporioides isolates from Limonium spp. were resistant to benomyl, the objectives of this study were to (i) characterize the benomyl-resistant and -sensitive populations and determine whether multiple genotypes of $C$. gloeosporioides are associated with propagation material and (ii) describe the molecular genetic basis for benomyl resistance among isolates of $C$. gloeosporioides from diseased Limonium spp. in Israel.

\section{MATERIALS AND METHODS}

Fungal strains, growth conditions, and plant material. We used previously characterized reference isolates of $C$. acutatum from strawberry (CA-TUT-149) and anemone (CA-ANE-HV83) and of $C$. gloeosporioides from avocado (CG-AVO-37-4B) $(16,17)$, and 64 monoconidial isolates of $C$. gloeosporioides from Limonium spp. (Table 1). The cultures of $C$. gloeosporioides were isolated arbitrarily from wilted plants of four susceptible cultivars (Misty, Beltlaard, Sunglow, and Supreme) at 12 farm locations in the Arava and Negev desert regions of southern Israel from 1997 to 2003. Cvs. Beltlaard, Misty, and Supreme originated from various distributors in Japan, India, South Korea, and the Netherlands, whereas cv. Sunglow was propagated by Ben Zur Nurseries and Laboratory Ltd., Tirat Yehuda, Israel.

Infected crowns and stems of Limonium spp. were surface disinfested for $3 \mathrm{~min}$ (30\% of dilute $0.03 \%$ household bleach) and plated on modified Mathur's medium (MS; $0.1 \%$ yeast extract, $0.1 \%$ bactopeptone, $1 \%$ sucrose, $0.25 \% \mathrm{MgSO}_{4} \cdot 7 \mathrm{H}_{2} \mathrm{O}, 0.27 \%$ $\mathrm{KH}_{2} \mathrm{PO}_{4}, 2 \%$ agar) supplemented with iprodione (Rovral 50WP; Rhone Poulenc, Lyon, France) at $2.5 \mu \mathrm{g} / \mathrm{ml}$ and acidified with $0.1 \%$ lactic acid to select for Colletotrichum and to suppress growth of fungal and bacterial contaminants (14). Cultures were grown on MS medium and maintained at $25^{\circ} \mathrm{C}$ in the dark. All cultures of Colletotrichum spp. from Limonium spp. were screened for sensitivity to benomyl (Benlate 50WP; DuPont, Wilmington, DE) at 1.0 and $10 \mu \mathrm{g} / \mathrm{ml}$. Benomyl-resistant strains were grown on MS medium supplemented with the fungicide at $10 \mu \mathrm{g} / \mathrm{ml}$ by placing a freshly cultured disk of the mycelium of each isolate in the center of $9-\mathrm{cm}$ plates containing amended medium. Subsequently, resistant isolates were maintained on MS medium supplemented with benomyl at $10 \mu \mathrm{g} / \mathrm{ml}$ for three to four consecutive transfers to verify resistance stability. Selected $C$. gloeosporioides isolates from Limonium spp. resistant (L11, L50, and LP3) and sensitive (L38, L46, and P1) to benomyl were thoroughly charac- terized morphologically in this study. For determination of size, 20 conidia of each isolate were selected per microscopic field on MS medium, and their average measurements were calculated.

Isolation and purification of fungal DNA. Fungal isolates were grown in $100 \mathrm{ml}$ of potato dextrose broth (PDB) at $24^{\circ} \mathrm{C}$ for 7 days. The mycelium was collected by vacuum filtration, lyophilized, and extracted and purified as previously described (18). Purified DNA was dissolved in $0.5 \mathrm{ml}$ of TE buffer $(10 \mathrm{mM}$ Tris$\mathrm{HCl}, 1 \mathrm{mM}$ EDTA, $\mathrm{pH} 8.0$ ) to an approximate concentration of 200 to $500 \mu \mathrm{g} / \mathrm{ml}$ and diluted to a final concentration of 10 to $100 \mathrm{ng} / \mu \mathrm{l}$ for polymerase chain reaction (PCR).

PCR amplification. For arbitrarily primed (ap)-PCR, the following primers that were derived from microsatellite or repeat sequences were used: $(\mathrm{CAG})_{5}(40),(\mathrm{AGG})_{5}(22)$, and $(\mathrm{GACA})_{4}$ (45). PCR primers for the C. gloeosporioides-specific diagnostic amplification were the universal internal transcribed spacer (ITS)4 primer (5'-TCCTCCGCTTATTGATATGC-3') coupled with specific primer $C g$ Int (5'-GGCCTCCCGCCTCCGGGCGG-3') (5). For amplification of the ITS- 1 and ITS- 2 regions between the small and large nuclear rDNA of seven selected benomyl-resistant (L11, L32, L50, L60, CG2, CG-L-P2, and CG-L-P3) and five benomyl -sensitive isolates (L28, L38, L46, L66, and P1), the universal primers ITS-5 (5'-GGAAGTAAAAGTCGTAACAAGG-3') and ITS-4 were used (16,17). PCR reactions were performed in a total volume of $20 \mu \mathrm{l}$, containing 10 to $100 \mathrm{ng}$ of DNA, $50 \mathrm{mM} \mathrm{KCl,} 10 \mathrm{mM}$ Tris-HCl, $0.2 \mathrm{mM}$ each dATP, dCTP, dGTP, and dTTP, $1.5 \mathrm{mM} \mathrm{MgCl}$, 1 unit of Taq DNA polymerase (Promega Corp., Madison, WI), and $1 \mu \mathrm{M}$ each primer. PCR reactions were incubated in a PTC-100 thermocycler (MJ Research, Inc., Watertown, MA) starting with 5 min of denaturation at $95^{\circ} \mathrm{C}$. For ap-PCR, this was followed by 30 cycles consisting of $30 \mathrm{~s}$ at $95^{\circ} \mathrm{C}, 30 \mathrm{~s}$ at either $60^{\circ} \mathrm{C}$ (for $(\mathrm{CAG})_{5}$ and $(\mathrm{AGG})_{5}$ ) or $48^{\circ} \mathrm{C}$ (for $(\mathrm{GACA})_{4}$ ), and $90 \mathrm{~s}$ at $72^{\circ} \mathrm{C}$. C. gloeosporioidesspecific PCR amplifications were performed under reaction conditions for primer $(\mathrm{CAG})_{5}$, with $0.5 \mu \mathrm{M}$ primer ITS-4 and $0.5 \mu \mathrm{M}$ primer $C g$ Int. For rDNA amplification, denaturation was followed by 40 cycles consisting of $30 \mathrm{~s}$ at $95^{\circ} \mathrm{C}, 30 \mathrm{~s}$ at $50^{\circ} \mathrm{C}$, and $90 \mathrm{~s}$ at $72^{\circ} \mathrm{C}$.

Amplification and subsequent sequencing of the DNA fragment of the $\beta$-tubulin gene TUB2 known to harbor mutation sites conferring benomyl resistance, from representatives of the benomylresistant isolates (L11, L32, L50, L60, and CG2), was performed with primer pair GENC (5'-GAGGAATTCCCAGACCGTATGATG-3') (27) and TUB2 (5'-GACATCCTTCATAGCG-3') (27)

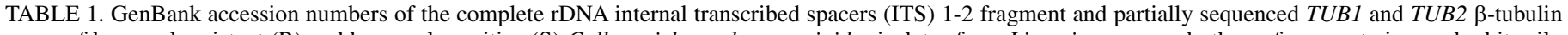

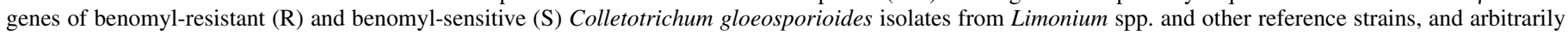
primed polymerase chain reaction (ap-PCR) groupings of isolates used in this study ${ }^{\mathrm{a}}$

\begin{tabular}{|c|c|c|c|c|}
\hline Isolate & ITS $1-2$ & $T U B 1$ & $T U B 2$ & ap-PCR group \\
\hline $\mathrm{L} 11(\mathrm{R})^{\mathrm{b}}$ & DQ185438 & DQ084499 & DQ084509 & 1 \\
\hline $\mathrm{L} 32(\mathrm{R})^{\mathrm{b}}$ & DQ185441 & DQ084500 & DQ084510 & 1 \\
\hline $\mathrm{L} 50(\mathrm{R})^{\mathrm{b}}$ & DQ084495 & DQ084501 & DQ084511 & 1 \\
\hline $\mathrm{L} 60(\mathrm{R})^{\mathrm{b}}$ & DQ084496 & DQ084502 & DQ084512 & 1 \\
\hline $\mathrm{CG} 2(\mathrm{R})^{\mathrm{b}}$ & DQ185439 & DQ084503 & DQ084513 & 1 \\
\hline $\mathrm{P} 1(\mathrm{~S})^{\mathrm{c}}$ & DQ084498 & DQ084504 & DQ084514 & 2 \\
\hline $\mathrm{L} 28(\mathrm{~S})^{\mathrm{c}}$ & DQ185440 & DQ084505 & DQ084515 & 2 \\
\hline $\operatorname{L} 38(\mathrm{~S})^{\mathrm{c}}$ & DQ084497 & DQ084506 & DQ084516 & 2 \\
\hline $\mathrm{L} 46(\mathrm{~S})^{\mathrm{c}}$ & DQ185442 & DQ084507 & DQ084517 & 2 \\
\hline $\mathrm{L} 66(\mathrm{~S})^{\mathrm{c}}$ & DQ185443 & DQ084508 & DQ084518 & 2 \\
\hline CG-L-P2 (R) & DQ185444 & nd & nd & 3 \\
\hline CG-L-P3 (R) ${ }^{\mathrm{d}}$ & DQ185445 & nd & nd & 4 \\
\hline C. graminicola $(37)$ & nd & M34491 & M34492 & nd \\
\hline C. gloeosporioides f. sp. aeschynomene (6) & nd & M90977 & U14138 & nd \\
\hline
\end{tabular}

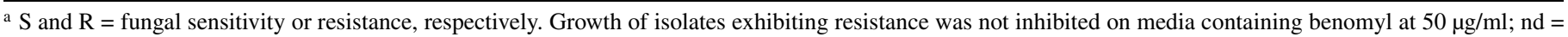
not determined.

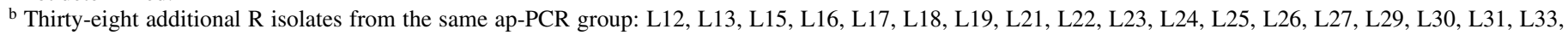
L34, L35, L36, L41, L42, L43, L48, L49, L51, L52, L53, L54, L55, L56, L57, L58, L59, L61, L62, and L63.

${ }^{c}$ Eighteen additional S isolates from the same ap-PCR group: L14, L20, L37, L39, L40, L44, L47, L64, L65, L67, L68, L69, and L70.

$\mathrm{d}$ One additional $\mathrm{R}$ isolate in the same ap-PCR group: CG2. 
and from representatives of benomyl-sensitive isolates (L28, L38, L46, L66, and P1) using primer pair GENC and TUB2B (5'GAC(A/G)TCCTTCAT(A/G)GCGA-3') based on specific sequences aligned with the intron of this gene from C. gloeosporioides f. sp. aeschynomene (unpublished data) and C. graminicola (37). A portion of the TUB1 gene was amplified by PCR with primers GENC and TUB 1C (5'-TCAATCTGCTTGGTCGACACCTT- $3^{\prime}$ ) (unpublished data). PCR reactions were performed in a total volume of $20 \mu \mathrm{l}$, containing 10 to $100 \mathrm{ng}$ of DNA, $50 \mathrm{mM}$ $\mathrm{KCl}, 10 \mathrm{mM}$ Tris-HCl, $0.2 \mathrm{mM}$ each dATP, dCTP, dGTP, and dTTP, $1.5 \mathrm{mM} \mathrm{MgCl}_{2}, 1$ unit Deep Vent DNA polymerase (New England Biolabs, Beverly, MA), and $0.5 \mu \mathrm{M}$ each primer pair. The reactions were incubated in a T-Gradient Biometra thermocycler (Göttingen, Germany) starting with $60 \mathrm{~s}$ of denaturation at $94^{\circ} \mathrm{C}$; followed by 35 cycles consisting of $30 \mathrm{~s}$ at $94^{\circ} \mathrm{C}, 30 \mathrm{~s}$ at $50^{\circ} \mathrm{C}$, and $60 \mathrm{~s}$ at $72^{\circ} \mathrm{C}$; and a final extension period of $10 \mathrm{~min}$ at $72^{\circ} \mathrm{C}$. Amplification products were separated in $1.5 \%$ agarose gels in Tris-acetate-EDTA buffer (42) at $8 \mathrm{~V} / \mathrm{cm}$ for $2 \mathrm{~h}$. All ap-PCR experiments were repeated at least four times. Variation in the apPCR banding patterns was interpreted visually.

DNA sequencing and sequence analysis. PCR-amplified $\beta$ tubulin and rDNA gene products were extracted from agarose gels with a Jetsorb kit (Genomed GmbH, Löhne, Germany). The Big Dye Terminator DNA sequencing kit (Perkin-Elmer Inc., Branchburg, NJ) and an ABI prism 377 DNA sequencer (Applied Biosystem Inc., Foster City, CA) at the sequencing unit of the Hebrew University of Jerusalem were used to sequence the DNA fragments. Identity of the sequenced fragments with $\beta$-tubulin genes from $C$. gloeosporioides $\mathrm{f}$. sp. aeschynomene and from C. graminicola was determined in a BLAST-X search and alignments were made with the CLUSTAL W program. The percent

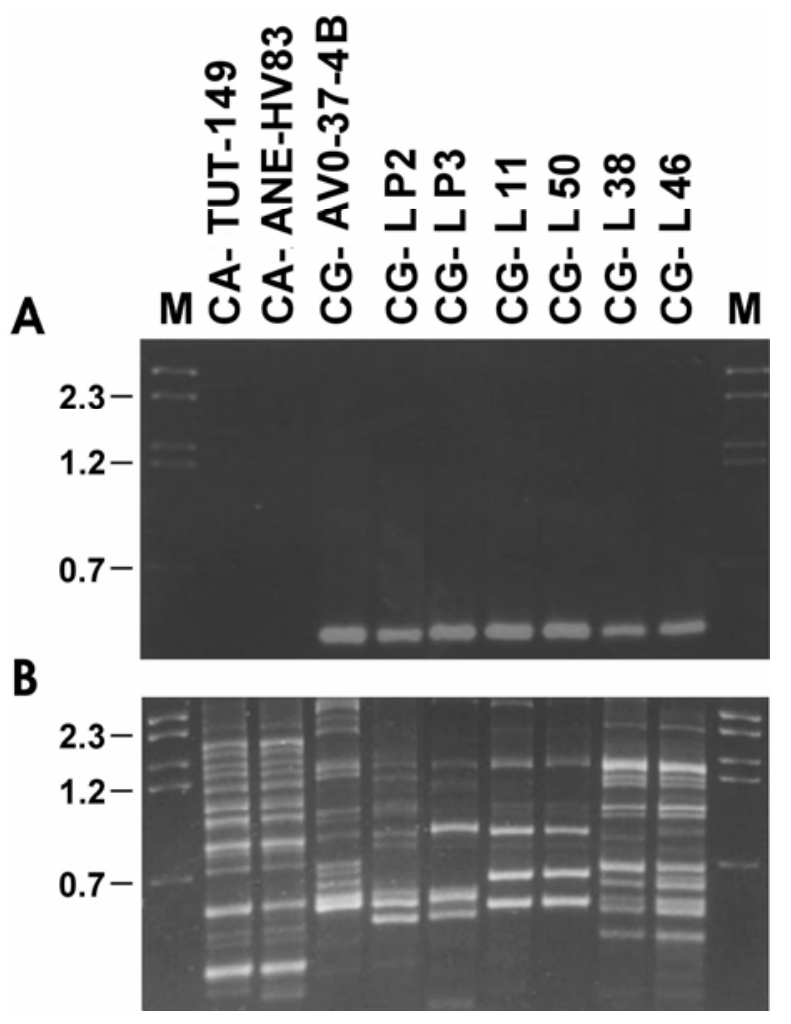

Fig. 1. Colletotrichum gloeosporioides-specific $\mathbf{A}$, amplification and $\mathbf{B}$, band patterns of arbitrarily primed polymerase chain reaction using primer (AGG) of genomic DNA from representatives of $C$. acutatum isolates from strawberry (CA-TUT-149) and anemone (CA-ANE-HV83), C. gloeosporioides isolate from avocado (CG-AVO 37-4B), and selected C. gloeosporioides isolates from Limonium spp. resistant (CG-L-P2, CG-L-P3, CG-L11, and CG-L50) and sensitive (CG-L38 and CG-L46) to benomyl. Lane M: DNA markers with sizes in kilobases. similarity between fragments of the different isolates was compared by Genedoc 2.5 .

Analyses of ITS-1 sequences (from seven benomyl-resistant and five benomyl-sensitive isolates) were carried out using the ARB program package (29). Alignment of sequences was performed with the ARB automated alignment tool and alignments were refined manually. Phylogenetic analyses were performed by applying ARB parsimony, distance matrix, and maximum-likelihood methods. Accession numbers of the ITS-1 fragments and partial TUB1 and TUB2 genes of C. gloeosporioides isolates from Limonium spp. used in this study have been submitted to GenBank and are listed in Table 1. Additional ITS-1 sequences of Colletotrichum spp., retrieved from the GenBank, are included in this study for comparison (Table 1).

\section{RESULTS}

Detection of benomyl-resistance and morphological characterization of Colletotrichum isolates. Resistant isolates of C. gloeosporioides from Limonium spp. (46 in number) grew at a similar rate on benomyl-amended MS medium compared with sensitive isolates (18 in number) cultured on nonsupplemented medium, whereas sensitive isolates did not grow at benomyl concentrations of either 1.0 or $10 \mu \mathrm{g} / \mathrm{ml}$. The selected isolates resistant (L11, L50, and LP3) and sensitive (L38, L46, and P1) to benomyl were identified and characterized within the C. gloeosporioides species aggregate by morphological criteria. Conidia from the resistant and sensitive populations were typical for C. gloeosporioides and could not be differentiated; they were all oblong, possessed cylindrical, rounded ends, and measured 11.0 to 18.0 by 5.0 to $7.0 \mu \mathrm{m}$. Setae, typical for $C$. fragariae, were not present in any of the colonies.

Species-specific primer amplification, ap-PCR, and ITS sequence analyses of Colletotrichum spp. isolates. C. gloeosporioides-specific amplification was conducted on all 64 isolates of Colletotrichum from Limonium spp., and 3 additional representative isolates (TUT-149, C. acutatum from strawberry; ANEHV83, C. acutatum from anemone; and AVO-37-4B, C. gloeosporioides from avocado) to verify species identification (Table 1). The $C$. gloeosporioides-specific $C g$ Int primer in conjunction with the ITS-4 primer amplified a 545-bp fragment from DNA of the representative isolate of $C$. gloeosporioides from avocado (AVO-37-4B), and from all isolates of C. gloeosporioides from Limonium spp. used in this study; however, no reaction was evident with DNA of two C. acutatum isolates, TUT-149 from strawberry or ANE-HV83 from anemone (Fig. 1A).

Genomic DNA from all isolates included in the species-specific

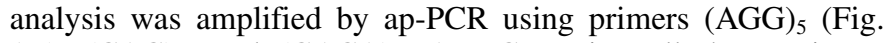
$1 \mathrm{~B}),(\mathrm{CAG})_{5}$, and $(\mathrm{GACA})_{4}$. Ap-PCR using all three primers consistently showed that the 43 benomyl-resistant and 18 benomyl-sensitive isolates of $C$. gloeosporioides from Limonium spp. belonged to two distinct genotypes (Table 1). Three additional resistant isolates produced distinct banding patterns and were assigned to groups 3 (isolates CG-LP2 and CG2) and 4 (isolate CG-LP3) (Table 1). Ap-PCR also distinguished between representative isolates of the different genotypes of $C$. acutatum and $C$. gloeosporioides from avocado.

ITS-1 sequence analysis was performed on representative isolates of ap-PCR groups 1 to 4 of C. gloeosporioides from Limonium spp. and additional representatives of the genus (Fig. 2). Sequence was identical among each of the representatives of group 1 and group 2. Isolates of group 4 were identical to group 1 , whereas isolate CG-LP2 of group 3 differed from groups 1 and 4 by one base pair change. Phylogenetic analyses based on parsimony, distance matrix, or maximum-likelihood methods produced similar tree topologies. Sequence analysis confirmed species identification for all isolates from Limonium spp. as C. gloeosporioides; however, resistant and sensitive isolates were 
grouped within separate clusters (Fig. 2). Thus, the resistant population was placed within a cluster containing isolates of Glomerella cingulata and C. gloeosporioides f. sp. aeschynomene, whereas the sensitive population grouped with a cluster closely related to the species $C$. fragariae and $G$. cingulata that was closely linked to another cluster containing isolates of C. musae (Fig. 2). Sequence analysis indicated an identity of 96.9\% between the benomyl-resistant and -sensitive populations. However, $100 \%$ identity was evident among specific reference isolates of Colletotrichum spp. and the two clusters with Limonium spp.

Characterization of the TUB2 $\beta$-tubulin gene from benomylresistant and -sensitive isolates of $C$. gloeosporioides. Partial $T U B 2$ gene sequences from representatives of resistant and sensitive isolates of $C$. gloeosporioides from Limonium spp. were $563 \mathrm{bp}$ in length. The deduced amino acid sequence of TUB2 from the five sensitive $C$. gloeosporioides isolates from Limonium spp. was identical to that of the sensitive $C$. gloeosporioides $\mathrm{f}$. sp. aeschynomene from A. virginica (L.) (Northern jointvetch) and C. graminicola isolates (data not shown). The common singlebase-pair mutation that changes codon 198 from GAG (glutamic acid) to GCG (alanine), rendering benomyl resistance, was observed in all resistant isolates of C. gloeosporioides from Limonium spp. (Fig. 3). Significant differences in similarity for the sequenced TUB2 fragment also were observed among the different populations (Table 2). The resistant isolates from Limonium spp. were more similar in sequence to the sensitive $C$. gloeosporioides f. sp. aeschynomene ( $98.6 \%$ similarity) than to the sensitive population from Limonium spp. (93.1\% similarity), indicating that this may be a different species (Table 2).

Characterization of the TUB1 $\beta$-tubulin gene from benomyl-resistant and -sensitive isolates of $C$. gloeosporioides. Amplified fragments of the TUB1 gene from both resistant and sensitive isolates of $C$. gloeosporioides from Limonium spp. were $506 \mathrm{bp}$ in size, based on sequence analysis. Sequences were compared with TUB1 $\beta$-tubulin genes from other isolates within each population and between isolates of $C$. gloeosporioides $\mathrm{f}$. sp. aeschynomene and $C$. graminicola (Table 2). Within the resistant genotype, all TUB1 sequences were identical, as were those within the sensitive isolates. Similarity of TUB1 fragments between benomyl-resistant and -sensitive isolates of $C$. gloeosporioides from Limonium spp. or C. gloeosporioides f. sp. aeschynomene isolates was 92.5 and $92.7 \%$, respectively (Table 2).

\section{DISCUSSION}

Some species of Colletotrichum can be identified reliably using specific PCR primers $(1,16,17)$. In this study, amplifications using species-specific primers indicated that all isolates of Colletotrichum affecting Limonium spp. in Israel belonged to C. gloeosporioides, although $C$. fragariae seems to be difficult to separate from $C$. gloeosporioides based only on this criterion. However, because this is a complex species including host-specific isolates that may be classified to the level of forma specialis, additional methods, such as morphological characters, are required to distinguish between genotypes within C. gloeosporioides $(1,2,8,15)$. According to morphological criteria, conidia of selected isolates from both benomyl-resistant and -sensitive populations were not borne on setae and possessed dimensions typical for C. gloeosporioides. In contrast, $C$. fragariae conidia are obovate, tapered to a truncate base, and are borne on setae $(1,21)$.

By using ap-PCR, two distinct genotypes corresponding to the benomyl-resistant and -sensitive populations from Limonium spp. were identified. Heterogeneity is common among populations of C. gloeosporioides, especially those possessing the teleomorphic stage $(1,8,15,34)$. Therefore, the discovery of the perfect stage of C. gloeosporioides, G. cingulata, on naturally infected Limonium spp. in Israel (4), Japan (25), and Korea (34) may be an additional factor contributing to genetic variability between the resistant and sensitive populations.

The benomyl-resistant and -sensitive populations of $C$. gloeosporioides from Limonium spp. were further characterized by their ITS-1 sequence diversity. Our data indicated that the resistant and sensitive genotypes shared $96.9 \%$ similarity. In previous studies, it was shown that an ITS-1 sequence similarity between 98.9 to $100 \%$ existed among isolates of $C$. gloeosporioides from different hosts, such as avocado, apple, mango, and strawberry $(1,13,14)$. This indicates that the two Limonium populations are as diverse as genotypes from various different hosts and suggests that these populations may be distinct species, even though these findings were based on the relatively conserved ITS regions. ITS1 sequences from the resistant population were identical to that of an isolate of $C$. gloeosporioides f. sp. aeschynomene, a species specific to the Northern jointvetch (A. virginica), whereas sequences of the sensitive population were identical to two isolates of $C$. fragariae, a pathogen specific to strawberry. This further indicates that the $C$. gloeosporioides populations affecting Limonium spp. are diverse, although conidial and setae morphology did not support these findings. In addition, analysis of partial sequences of the two $\beta$-tubulin genes corroborated that these popu-

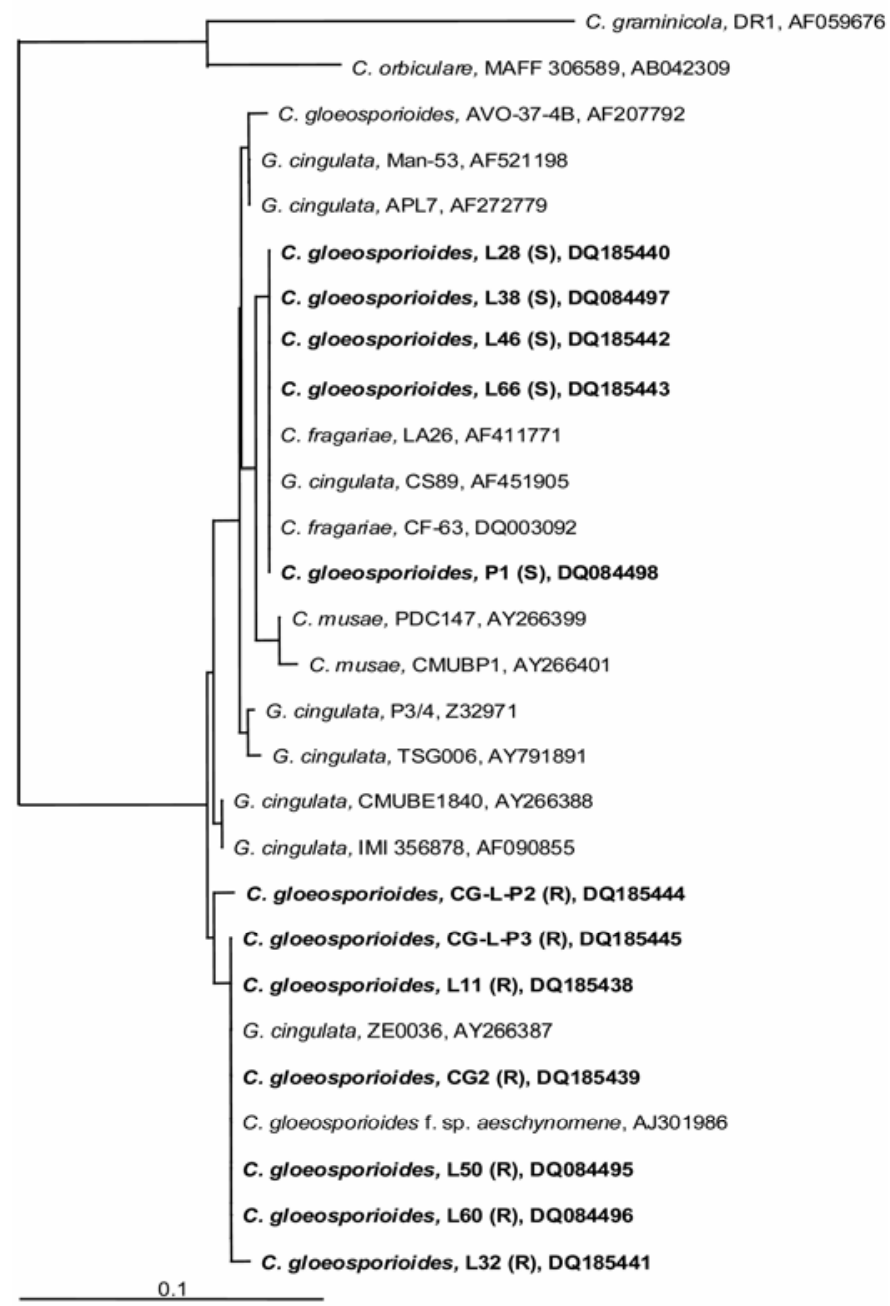

Fig. 2. Internal transcribed spacer-1-based phylogenetic tree of Colletotrichum isolates used in this study. Benomyl-resistant (R) and -sensitive (S) isolates of Colletotrichum gloeosporioides from Limonium spp., including respective accession numbers, appear in bold print. Accession numbers of additional Colletotrichum sequences retrieved from the GenBank that are closely related to those of C. gloeosporioides isolates from Limonium spp. are included for comparison. The tree was produced using the neighbor-joining algorithm (29). The order of branching was similar in all tree construction approaches used. Scale bar indicates estimated $10 \%$ sequence divergence. 
Fig. 3. Partial nucleotide sequence of the $\beta$-tubulin TUB2 gene from different isolates of Colletotrichum: L38 of Colletotrichum gloeosporioides from Limonium spp., sensitive to benomyl; L50 of C. gloeosporioides from Limonium spp., naturally resistant to benomyl; C. gloeosporioides f. sp. aeschynomene (C.g.a) from Aeschynomene virginica, sensitive to benomyl (6); and C. graminicola (C.gra) from corn, sensitive to benomyl (37). The respective conversion in codon 198, from GAG (glutamic acid) to GCG (alanine), denoting the sensitive (L38) as opposed to resistant (L50) isolates of C. gloeosporioides from Limonium spp., is underlined and in bold. Intron sequences are in bold and primer sequences (GEN C, forward and TUB 2B, reverse) are underlined.

lations are uniquely different; namely, that the resistant population is more closely related to $C$. gloeosporioides f. sp. aeschynomene than to the sensitive population. Furthermore, in a preliminary study, it was shown that the resistant and sensitive populations belong to two distinct vegetative compatibility groups (4).

Cross-infection potential exists between certain groups of C. gloeosporioides on a variety of plants, and different species can infect a single host $(1,2,19)$. This indicates that the potential exists for different genotypes of $C$. gloeosporioides to infect a single host, such as Limonium spp.; however, natural crossinfections in the field need to be assessed.
The majority $(\approx 75 \%)$ of isolates from diseased statice in Israel were resistant to the fungicide benomyl. Resistance to benzimidazole fungicides has been reported in many filamentous fungi, whereby the fungicide is unable to bind to a mutated $\beta$-tubulin protein containing an altered amino acid sequence (11). In the majority of cases studied, a single $\beta$-tubulin gene exists within the fungal genome; however, in others, an additional gene may be present that is divergent in sequence. Single copies of the gene, responsible for benomyl resistance when mutated, have been reported in Saccharomyces cerevisiae (35), Septoria nodorum (9), Monilinia fructicola (30,43), Gibberella pulicaris (26), Neuro- 
TABLE 2. Matrix of similarity (\%) between isolates of Colletotrichum spp. based on sequence comparisons of fragments of the TUB2 and TUB1 $\beta$-tubulin genes ${ }^{\text {a }}$

\begin{tabular}{|c|c|c|c|c|}
\hline \multirow[b]{2}{*}{ Isolate } & \multicolumn{4}{|c|}{$T U B 2 / T U B 1$ genes } \\
\hline & L38 (S) & L50 (R) & C. gloeosporioides f. sp. aeschynomene (S) & C. $\operatorname{graminicola}(\mathrm{S})$ \\
\hline L38 (S) & $\ldots$ & $\ldots$ & $\ldots$ & $\ldots$ \\
\hline $\mathrm{L} 50(\mathrm{R})$ & $93.1 / 92.5$ & $\ldots$ & $\ldots$ & $\ldots$ \\
\hline C. gloeosporioides f. sp. aeschynomene $(\mathrm{S})$ & $94.0 / 90.5$ & $98.6 / 92.7$ & $\ldots$ & $\ldots$ \\
\hline C. $\operatorname{graminicola}(\mathrm{S})$ & $87.3 / 74.5$ & $86.8 / 74.5$ & $87.3 / 73.7$ & $\ldots$ \\
\hline
\end{tabular}

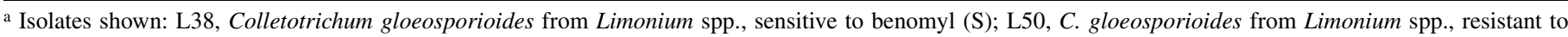
benomyl (R); C. gloeosporioides f. sp. aeschynomene from Aeschynomene virginica (S); and C. graminicola from corn (S).

spora crassa (36), Venturia inaequalis (27), Botrytis cinerea (47), Tapesia spp. (3), and other fungi (7). The presence of two such genes has been reported in only a few fungi: Aspergillus nidulans (24,31), Trichoderma spp. (20,33), and Colletotrichum spp. (6,37). In C. graminicola (37) and C. gloeosporioides f. sp. aeschynomene (6), the two $\beta$-tubulin genes, TUB1 and TUB2, are highly divergent. Similar results were obtained in this study when comparing the two partial gene sequences from benomyl-resistant and -sensitive isolates of $C$. gloeosporioides from Limonium spp., further indicating that these two populations may be different species. Of the two $\beta$-tubulin genes in Colletotrichum, the TUB2 fragment was more closely related in sequence to $B$. cinerea benA and $\beta$ tubulin genes from other fungi than to that of $T U B 1(6,37,46)$.

Analysis of the $\beta$-tubulin TUB2 region that is responsible for benomyl resistance showed that the typical single-base-pair mutation converting codon 198 from glutamic acid to alanine $(27,47)$ was observed in the resistant but not the sensitive isolates of C. gloeosporioides from Limonium spp. (Fig. 3). In general, various levels of resistance to benomyl have been reported for certain fungi (e.g., "very high resistance" to the fungicide was reported for the pathogens Venturia inaequalis, V. pirina, Penicillium puberulum, $P$. expansum, and $P$. aurantiogriseum, all possessing the same mutation) (27). With the stone fruit pathogen Monilinia fructicola, "high levels of resistance" were associated with the same conversion at codon 198 (30). Furthermore, "highly resistant" isolates of the gray mold pathogen, $B$. cinerea, had the identical mutation $(28,47)$. Although no fungicide spray regime documentation is available from the overseas suppliers of the Limonium plantlets to Israeli growers, it is plausible to assume that the mutation leading to benomyl resistance was not derived in Israel. This is further substantiated by the fact that farmers in Israel do not apply benomyl to their Limonium crop under cultivation.

The presence of two different $C$. gloeosporioides genotypes from Limonium spp. in Israel may indicate that two separate introductions of infected propagation material occurred. Additional genotypes (groups 3 and 4) were identified that may represent additional introductions. Furthermore, cross-infection of Limonium spp. by $C$. gloeosporioides may be occurring due to cultivation of this crop in close proximity to mango, citrus, avocado, ornamentals, and other indigenous hosts that are infected with $C$. gloeosporioides that may provide inoculum for infection of Limonium spp. in Israel.

In summary, the pathogen $C$. gloeosporioides that is responsible for wilting of Limonium spp. in Israel is composed of both benomyl-resistant (characterized with a typical mutation in the TUB2 $\beta$-tubulin gene at codon 198) and benomyl-sensitive populations that are genetically distinct. Because benomyl is not applied to this crop in Israel, the pathogen populations may be (i) originating as quiescent infections on imported plantlets, (ii) dispersed locally from plot to plot among the different growers by workers in the fields, or (iii) cross-infecting Limonium spp. from alternate hosts cultivated adjacent to the affected crops.

\section{ACKNOWLEDGMENTS}

This research was partially supported by grant no. 132-1029 from the Chief Scientist, Israel Ministry of Agriculture awarded to S. Freeman.
Contribution No. 518/04 from the ARO, Institute of Plant Protection. We thank O. Yarden from the Hebrew University Jerusalem for helpful discussions during this study.

\section{LITERATURE CITED}

1. Afanador-Kafuri, L., Minz, D., Maymon, M., and Freeman, S. 2003. Characterization of Colletotrichum isolates from tamarillo, passiflora and mango in Colombia and identification of a unique species from the genus. Phytopathology 93:579-587.

2. Alahakoon, P. W., Brown, A. E., and Sreenivasaprasad, S. 1994. Crossinfection potential of genetic groups of Colletotrichum gloeosporioides on tropical fruits. Physiol. Mol. Plant Pathol. 44:93-103.

3. Altertini, C., Gredt, M., and Leroux, P. 1999. Mutations of the $\beta$-tubulin gene associated with different phenotypes of benzimidazole resistance in the cereal eyespot fungi Tapesia yallundae and Tapesia acuformis. Pestic. Biochem. Physiol. 64:17-31.

4. Bar Lavan, Y., Pivonia, S., Katan, J., Zveibil, A., and Freeman, S. 2004. Characterization, survival and affect of heat treatments on Colletotrichum gloeosporioides, causal agent of Limonium decline. Phytoparasitica 32:188.

5. Brown, A. E., Sreenivasaprasad, S., and Timmer, L. W. 1996. Molecular characterization of slow-growing orange and Key lime anthracnose strains of Colletotrichum from citrus as C. acutatum. Phytopathology 86:523527.

6. Buhr, T. L., and Dickman, M. B. 1994. Isolation, characterization, and expression of a second beta-tubulin-encoding gene from Colletotrichum gloeosporioides f. sp. aeschynomene. Appl. Environ. Microbiol. 60:41554159.

7. Caten, C. E. 1996. The mutable and treacherous tribe revisited. Plant Pathol. 45:1-12.

8. Cisar, C. R., Spiegel, F. W., TeBeest, D. O., and Trout, C. 1994. Evidence for mating between isolates of Colletotrichum gloeosporioides with different host specificities. Curr. Genet. 25:330-335.

9. Cooley, R. N., and Caten, C. E. 1993. Molecular analysis of the Septoria nodorum beta-tubulin gene and characterization of a benomyl-resistant mutation. Mol. Gen. Genet. 237:58-64.

10. Correll, J. C., Rhoads, D. D., and Guerber, J. C. 1993. Taxonomic, mtDNA haplotype, VCG, and morphological diversity of Colletotrichum spp. causing fruit-rot of apples. Phytopathology 83:1412-1413.

11. Davidse, L. C., and Flach, W. 1977. Differential binding of methyl-benzimidazole-2-yl carbamate to fungal tubulin as a mechanism of resistance to this antimitotic agent in mutant strains of Aspergillus nidulans. J. Cell Biol. 72:174-193.

12. Engelhard, A. W. 1975. Etiology, symptomatology, and economic importance of the diseases of annual statice (Limonium spp.). Plant Dis. Rep. 59:551-555.

13. Engelhard, A. W., Howard, C. M., and Wilfret, G. J. 1972. A new crown rot, leaf and scape spot disease of statice (Limonium sinuatum) incited by Colletotrichum sp. Plant Dis. Rep. 56:894-895.

14. Freeman, S., and Katan, T. 1997. Identification of Colletotrichum species responsible for anthracnose and root necrosis of strawberry in Israel. Phytopathology 87:516-521.

15. Freeman, S., Katan, T., and Shabi, E. 1998. Characterization of Colletotrichum species responsible for anthracnose diseases of various fruits. Plant Dis. 82:596-605.

16. Freeman, S., Minz, D., Jurkevitch, E., Maymon, M., and Shabi, E. 2000. Molecular analyses of Colletotrichum species from almond and other fruits. Phytopathology 90:608-614.

17. Freeman, S., Minz, D., Maymon, M., and Zveibil, A. 2001. Genetic diversity within Colletotrichum acutatum sensu Simmonds. Phytopathology 91:586-592.

18. Freeman, S., Pham, M., and Rodriguez, R. J. 1993. Molecular genotyping of Colletotrichum species based on arbitrarily primed PCR, A + T-rich DNA, and nuclear DNA analyses. Exp. Mycol. 17:309-322.

19. Freeman, S., and Shabi, E. 1996. Cross-infection of subtropical and tem- 
perate fruits by Colletotrichum species from various hosts. Physiol. Mol. Plant Pathol. 49:395-404.

20. Goldman, G. H., Temmerman, W., Jacobs, D., Contreras, R., Van Montagu, M., and Herrera-Estrella, A. 1993. A nucleotide substitution in one of the beta-tubulin genes of Trichoderma viride confers resistance to the antimitotic drug methyl benzimidazole-2-yl carbamate. Mol. Gen. Genet. 240:73-80.

21. Gunnell, P. S., and Gubler, W. D. 1992. Taxonomy and morphology of Colletotrichum species pathogenic to strawberry. Mycologia 84:157-165.

22. Gupta, M., and Filner, P. 1991. Microsatellites amplify highly polymorphic DNA bands in SPAR of plant DNA. Abstr. 1705 in: Proc. Int. Soc. Plant Mol. Biol., Tucson, AZ.

23. Jayasinghe, C. K., and Fernando, T. H. P. S. 2000. Fungicide sensitivity of two Colletotrichum species pathogenic to rubber. Int. J. Trop. Plant Dis. 18:77-85.

24. Jung, M. K., Wilder, I. B., and Oakley, B. R. 1992. Amino-acid alterations in the BenA (beta-tubulin) gene of Aspergillus nidulans that confer benomyl resistance. Cell Motil. Cytoskelet. 22:170-174.

25. Kagiwata, T. 1986. An anthracnose of statice (Limonium sinuatum) caused by Colletotrichum gloeosporioides Penzig. J. Agric. Sci. Jpn. 31:101-110.

26. Kawchuk, L. M., Hutchison, L. J., Verhaeghe, C. A., Lynch, D. R., Bains, P. S., and Holley, J. D. 2002. Isolation of the $\beta$-tubulin gene and characterization of thiabendazole resistance in Gibberella pulicaris. Can. J. Plant Pathol. 24:233-238.

27. Koenraadt, H., Somerville, S. C., and Jones, A. L. 1992. Characterization of mutations in the beta-tubulin gene of benomyl-resistant field strains of Venturia inaequalis and other plant pathogenic fungi. Phytopathology 82:1348-1354.

28. Luck, J. E., and Gillings, M. R. 1995. Rapid identification of benomyl resistant strains of Botrytis cinerea using the polymerase chain reaction. Mycol. Res. 99:1483-1488.

29. Ludwig, W., Strunk, O., Westram, R., Richter, L., Meier, H., Yadhukumar, Buchner, A., Lai, T., Steppi, S., Jobb, G., Förster, W., Brettske, I., Gerber, S., Ginhart, A.W., Gross, O., Grumann, S., Hermann, S., Jost, R., König, A., Liss, T., Lüßmann, R., May, M., Nonhoff, B., Reichel, B., Strehlow, R., Stamatakis, A., Stuckmann, N., Vilbig, A., Lenke, M., Ludwig, T., Bode, A., and Schleifer, K. 2004. ARB: A software environment for sequence data. Nucleic Acids Res. 32:1363-1371.

30. Ma, Z., Yoshimura, M. A., and Michailides, T. J. 2003. Identification and characterization of benzimidazole resistance in Monilinia fructicola from stone fruit orchards in California. Appl. Environ. Microbiol. 69:71457152.

31. May, G. S., Tsang, M. L. S., Smith, H., Fidel, S., and Morris, N. R. 1987. Aspergillus nidulans $\beta$-tubulin genes are unusually divergent. Gene 55:231-243.

32. McKay, G. J., Egan, D., Morris, E., and Brown, A. E. 1998. Identification of benzimidazole resistance in Cladobotryum dendroides using a PCR- based method. Mycol. Res. 102:671-676.

33. Mukherjee, M., Hadar, R., Mukherjee, P. K., and Horwitz, B. A. 2003. Homologous expression of a mutated beta-tubulin gene does not confer benomyl resistance on Trichoderma virens. J. Appl. Microbiol. 95:861867.

34. Nam, M. H., Yoo, S. J., and Kim, H. G. 1996. Relationship between virulence and vegetative compatibility group of Glomerella cingulata isolates. Korean J. Plant Pathol. 12:395-401.

35. Neff, N. F., Thomas, J. H., Grisafi, P., and Botstein, D. 1983. Isolation of the $\beta$-tubulin gene from yeast and demonstration of its essential function in vivo. Cell 33:211-219.

36. Orbach, M. J., Porro, E. B., and Yanofsky, C. 1986. Cloning and characterization of the gene for beta-tubulin from a benomyl-resistant mutant of Neurospora crassa and its use as a dominant selectable marker. Mol. Cell. Biol. 6:2452-2461.

37. Panaccione, D. G., and Hanau, R. M. 1990. Characterization of two divergent beta-tubulin genes from Colletotrichum graminicola. Gene 86:163170.

38. Peres, N. A. R., Souza, N. L., Peever, T. L., and Timmer, L. W. 2004. Benomyl sensitivity of isolates of Colletotrichum acutatum and C. gloeosporioides from citrus. Plant Dis. 88:125-130.

39. Pivonia, S., Levita, R., Tzuberi, G., Zveibil, A., Nizani, Y., and Freeman, S. 2000. Decline of perennial Limonium cultivars caused by Colletotrichum gloeosporioides. Phytoparasitica 28:286-287.

40. Rodriguez, R. J., and Yoder, O. C. 1991. A family of conserved repetitive DNA elements from the fungal plant pathogen Glomerella cingulata (Colletotrichum lindemuthianum). Exp. Mycol. 15:232-242.

41. Sakoda, T., and Kimishima, E. 2003. Pathogenicity of some isolates of Verticillium tricorpus and Colletotrichum capsici found in Japan. Res. Bull. Plant Prot. Ser. Jpn. 39:103-107.

42. Sambrook, J., Fritsch, E. F., and Maniatis, T. 1989. Molecular Cloning: A Laboratory Manual. 2nd ed. Cold Spring Harbor Laboratory, Cold Spring Harbor, NY.

43. Sanoamuang, N., Gaunt, R. E., and Fautrier, A. G. 1995. The segregation of resistance to carbendazim in sexual progeny of Monilinia fructicola. Mycol. Res. 99:677-680.

44. Sobers, E. K., and Cox, R. S. 1973. Anthracnose of statice in Southern Florida. Phytopathology 63:193-194.

45. Weising, K., Weigand, F., Driesel, A. J., Kahl, A. J., Zischer, H., and Epplen, J. T. 1989. Polymorphic simple GATA/GACA repeats in plant genomes. (Abstr.) Nucleic Acids Res. 17:10128.

46. Yan, K., and Dickman, M. B. 1996. Isolation of a $\beta$-tubulin gene from Fusarium moniliforme that confers cold-sensitive benomyl resistance. Appl. Environ. Microbiol. 62:3053-3056.

47. Yarden, O., and Katan, T. 1993. Mutations leading to substitutions at amino acid 198 and 200 of beta-tubulin that correlate with benomylresistant phenotypes of field strains of Botrytis cinerea. Phytopathology $83: 1478-1483$ 